\title{
articles CAMCORDER JOHN AND MEDIA NARRATIVES: The role of informal communication in participative journalism
}

Copyright (c) 2015 SBPjor / Associação Brasileira de Pesquisadores em Jornalismo
MÍRIAM CRISTINA CARLOS SILVA

Universidade de Sorocaba, Brazil

\begin{abstract}
This article is part of a study supported by the Research Council for the State of São Paulo (FAPESP). It presents the work of an informal communicator called Camcorder John who, despite having only an elementary school education, works informally as a producer in Campina do Monte Alegre, in São Paulo, Brazil. His prospective stories reach regional, national and international media. This study uses interviews and analyses of narratives in order to narrate, describe, organize and analyze some of the practices that include Camcorder John's stories in media narratives. As its theoretical foundation, the study uses some discussions taken from Benjamin, Sodré, Meditsch, Pontes and Silva. The conclusion is that Camcorder John is a contemporary narrator who has learned both the language of media and the jargon of media professionals; he plays the role of a narrator who is aware of the symbolic power of his narrating.
\end{abstract}

Keywords: Media narratives; Narrator; Camcorder John.

\section{CAMCORDER JOHN AND MEDIA NARRATIVES: The role of informal communication in participative journalism}

RESUMO - Este artigo é parte da pesquisa apoiada pela Fundação de Amparo à Pesquisa do Estado de São Paulo. Apresenta-se o trabalho de João da Filmadora, comunicador informal que, apesar de ter concluído apenas o primeiro ciclo do ensino fundamental, atua como produtor informal na cidade de Campina do Monte Alegre, SP. Suas sugestões de pautas chegam às mídias regionais, nacionais e internacionais. Os objetivos consistem em, a partir de entrevistas e da análise de narrativas, narrar, descrever, organizar e analisar parte das práticas que inserem as pautas de João da Filmadora nas narrativas midiáticas. $\mathrm{O}$ aporte teórico se faz a partir das discussões de Benjamin, Sodré, Meditsch e Pontes e Silva. Conclui-se que João da Filmadora é um narrador contemporâneo que se apropriou tanto da linguagem dos meios quanto dos jargões dos profissionais da comunicação e que exerce seu papel de narrador, ciente do poder simbólico de suas narrativas.

Palavras-chave: Narrativas midiáticas; Narrador; João da Filmadora. 


\section{JUAN DE LA VIDEOCÁMARA Y LAS NARRATIVAS MEDIATICAS: \\ El papel de la comunicación informal en el periodismo participativo}

RESUMEN - Este artículo es parte de una investigación, con apoyo de la Fundación para la Investigación del Estado de São Paulo. Juan de la Videocámara, a pesar de haber completado sólo el primer grado de educación primaria, actúa como productor informal en Campina do Monte Alegre, SP, Brasil. Las sugerencias de Juan llegan a los medios de comunicación, regionales, nacionales e internacionales. Los objetivos son narrar, describir, organizar y analizar parte de las actividades que caen dentro de las agendas de Juan de la Videocámara en las narrativas en los medios. El aporte teórico se hace de las discusiones de Benjamin, Sodré, Meditsch, Pontes y Silva. Juan de la Videocámara es un narrador contemporáneo que se ha apropiado del lenguaje de los medios y de las jergas de los profesionales de comunicación, allende ejercer el papel de narrador, consciente del poder simbólico de sus historias.

Palabras clave: Narrativas en los medios de comunicación; Narrador; Juan de la Videocámara.

\section{THE NARRATOR: CAMCORDER JOHN}

This study looks at media narratives taken from interviews and news readings of the prospective stories offered to the media by 47-year old João Gomes Neto, also known as Camcorder John. He was born and lives in Campina do Monte Alegre, a small town of 6,000 residents in the interior of São Paulo. He has had the nickname Camcorder John since the 90's, when he acquired his first VHS camera and began producing amateur film about the city, its inhabitants and its history.

Over time, Camcorder John started to take his stories and transform them into short news clippings recorded on VHS. He would either send them to the media himself or reporters would call him and pick them up from him. Due to the impact his stories had (most were tales of ghosts, fables and urban legends) he began distributing prospective stories which were well received by both national and international media networks. That was how this simple, shy, quiet Caboclo' boy with only a fourth-grade education became an informal communicator in Campina, or as he calls himself, a "self-taught producer". The first person to identify him as such was Gerson de Souza, a journalist at Record Television Network². 
In 2008, Camcorder John started using the internet and created a network of contacts with professional journalists. They often used his narratives as well as distributing them among their peers as a source for diverse topics such as: a) Traditional myths like the saci ${ }^{3}$ inside a bottle ${ }^{4}$, the hen with gold in its gizzard ${ }^{5}$, the ghost train ${ }^{6}$, and the treasure buried on the banks of the Paranapanema river; ${ }^{7}$ ) Daily news from Campina do Monte Alegre like the story of a bull that was raised as a pet $^{8}$, the custom of not locking doors, windows and cars $^{9}$, and exotic fruit grown by a local farmerio; c) Heroic profiles such as Jorgina, a woman who is able to do all her daily activities by herself ${ }^{11}$ despite missing parts of her arms and legs; d) Historical and informative narratives like the one about the 1932 Revolution when the city of Campina turned into an important battle field where the Paulistas from the Southern Sector Constitutionalist Army fought troops from the Rio Grande do Sul Military Brigade, the Pernambuco Public Force and the Brazilian Army. One of the prospective stories was about some rifle shells, handguns and the nose cones of canons that had been found both in the city museum and in the hands of some private collectors ${ }^{12}$. Another historical and widespread narrative was the "Nazi Farm" which generated regional, national and international attention. This is the story of a farm in Campina do Monte Alegre called Cruzeiro do Sul. The farm's owner - a suspected Nazi supporter - had adopted around 50 children and submitted them to slavery. The source for this story is based on the report and the evidence found by José Ricardo Maciel, a resident of Campina who is married to the farm's current owner. While he was making repairs to the pigpen, Maciel found some bricks with swastikas on them. He also found pictures of cattle that had been branded with the Nazi symbol. Another one of Camcorder John's eye witness accounts was that of Aloísio Silva, a survivor from the farm ${ }^{13}$. The reports were compiled for historian Sidney Aguiar Filho's Doctorate research which was presented at the University of Campinas in 2011. The work had a large impact and increased media interest on the issue. The groundbreaking story was reported by Roberto Cabrini in 2008 and broadcast on the television program Domingo Espetacular, on the Record Television Network. The report also caught the attention of other media networks which sent journalists to Campina do Monte Alegre and published reports in the first semester of 2014, among them: BBC News, The Sun, Der Spiegel, So Foot, and CCTV from China. In all the cases, it was Camcorder John who, despite only being able to speak Portuguese, managed to guide the foreign production as a local contact. He states that "he was amazed at having international numbers on his mobile phone"14. 


\title{
2 CAMCORDER JOHN'S STORY: THE CONSTRUCTION OF NARRATIVES
}

There is only one newspaper in Campina do Monte Alegre, The Informativo, and one community radio station, Atrativa FM (105.9). In a series of interviews made available for this study, Camcorder John explained how he does his job as an informal communicator. His status within the local media is not a prominent one. He says he sometimes calls the radio station just because he feels he wants to report on something, nothing more. It might be fair to say that the local media do not value his work, but conversely, it is also fair to say that he is not too interested in working for local media outlets. One possible explanation for the low number of Camcorder John's reports in local media is the fact that the people of Campina do not regard his stories as being newsworthy. However, his participation in regional media (TV Tem in Itapetininga, TV Tem in Sorocaba and the Sorocaba newspaper (ruzeiro do Sul) is quite frequent. He contacts these media outlets, and national ones, by telephone or social media. His prospective stories are mainly oral narratives that Camcorder John himself tells his journalist contacts. Despite his difficulties in writing, this does not prevent him from making releases (as he calls them) and putting these oral narratives into writing, as in the example:

\begin{abstract}
Strange noises in the sky frighten the people in Campina do Monte Alegre, in the countryside of São Paulo. A still unexplained phenomenon has been witnessed in several areas of the city. Very peculiar sounds from an unknown source. One of the first of these sounds to be heard was in the district of Papagaio (parrot). They are usually metal sounds, as if coming from a big machine. Some witnesses state that the sound is so high that the windows tremble from the frequency of the sound waves. The noise was called Ghost Train. (sic). ${ }^{15}$
\end{abstract}

On Camcorder John's Facebook page (https://www.facebook.com/ filmadora.filmadora?fref=ts) you can find micro-narratives and phrases that draw attention to the material. Among the most recent ones is a kind of invitation posted on May $20^{\text {th }}, 2015$ asking that anyone who has a good story should tell it, and that he would act as a mediator between the story and the media. "If someone has a good story to tell, something exciting, breakthrough, unusual, "something curious"; it could be a story for the television. If you have anything, I'm available on chat" (sic). In another post he reproduces a micro-narrative from a character which he attempted to transform into a story, also including a video of the character himself. 
Good afternoon friends of kiko maranhão from all over Brazil. This video will show you all how I lived as kiko maranhão here in Maranhão; I dream of making a living with my music, but until this day comes, my life is working in the country during the week and, on the weekend, I enjoy my forról6. I am fighting hard for my dreams; I want to smile again so that I can sing happily to the ones who enjoy seeing me sing. This is a little of my life story here in Maranhão; here is João Gomes Neto Gomes (sic).

Other posts are just titles, like the one posted on May $19^{\text {th }}$, 2015: "Two classmates find out they were switched at birth in the hospital 19 years later". The following short narrative is also from May $19^{\text {th }}$.

Irineu Gomes has been raising chickens for 50 years. He states there is a flock of birds that lay blue eggs (actually, almost green). Mr. Comes became famous for this in the little town of Campina do Monte Alegre, in the countryside of São Paulo. He says that when he realized that some hens lay blue eggs, he began to select them. Mr. Gomes says that the "special" hens do not lay eggs of another color.

It is evident that despite his difficulties related to his low education level, the narratives are constructed in a language reflective of the journalistic style. Adriana dos Santos's comments posted on April $30^{\text {th }}$ reflect on Camcorder John's work as an informal communicator, regarding him as being on the same level as a journalist.

I remember when you sent this story and so many others to the Record Network!!! It is not the university that makes a good professional; and it is not high grades that make a good student. (Congratulations John, for having the school of life. You are not an office writer; you know the people's stories because you are not confined to an office).

Adriana's comments are a reflection of how important John Camcorder's work is for the city and also for the controversy his dual recognition generates; both the admiration and criticism from the population of Campina.

Campina do Monte Alegre, although part of the administrative region of Sorocaba, is not one of the cities covered by TV Tem Sorocaba. Instead, it is covered by TV Tem Itapetininga and Camcorder John's stories garner the attention of both Globo TV affiliates.

Camcorder John got his first camera in the 1980's when his father, Sebastião Roque Gomes, thanks to his son's insistence, exchanged a plot of land for the VHS camera. At that time, contact with the media was made by telephone. From 1990 onwards, with the onset of the internet and the mobile phone, he managed to 
increase his contact network and began submitting stories not only in Campina do Monte Alegre, but also in surrounding cities, and even ones in other states. Journalist Mariana Gomes ${ }^{17}$, network manager at the Rede Record Special Report Centre, recognizes Camcorder John's creativity and she says that he often submits story ideas for the section "Por onde anda" (Where are they now) which reports on the whereabouts of celebrities who have disappeared from the media spotlight, as well as other stories and editorials which Camcorder John constantly looks for.

He regards himself as an attentive observer of his surrounding reality, looking for anything that might be considered a good story. It is an observation that allows for fact to be transformed into narrative. In journalism, a simple event is not enough to be considered news; that event needs to be observed, interpreted and recorded by a narrator. This is how John gets his stories and, depending on the media interest they garner, they either become news or do not.

According to Park (1972), a fact is characterized by elements, and the meaning of these elements is then shared with all members of a group. Meditsch's (2010, p. 38) view on this is: "Nonetheless, however more elementary, consensual and evident the facts seem to be, they are still human productions". Referencing various authors (among whom are Park, Berger and Luckman, Genro Filho, and Lipman ${ }^{18}$, Meditsch (2010) discusses objectivity and subjectivity under the complexity of inter-subjectivity; elements that operate the construction of facts. Meditsch states that "credulous objectivism contradicts credulous subjectivism" (p. 19) in that "the metaphor for the whole exteriority contradicts with the whole media-centric internalization, which then leads to the absurd logic that the construction of reality is consumed by the prominence of media" (p. 19).

Looking at the world in his unique way, Camcorder John relates the inter-subjectivity that is meshed within contacts to traditional narrators and media narratives, and he states that while he is thinking about his stories, he is looking for unusual facts. After observing an event that might be considered newsworthy, he will talk to possible witnesses who could give statements. He himself is not usually the character in his stories, he only narrates on them like a kind of interpreter or observer-narrator of the facts. He also reports on oral narratives; popular culture and its myths, as well as some aspects of daily life in Campina which are unusual: the day-to-day life of a hillbilly and the way they live, the peculiarities of a small town 
where hardly anything happens yet where much is remembered, imagined and created. He also submits some narratives told by former residents. He says that his stories are simple and objective and that he sends them on to TV network affiliates and other media outlets, and only considers his work finished once he gets an affirmative response from one of the media sources. Mariana Gomes ${ }^{19}$ highlights Camcorder John's insistence, persistence and insightfulness. He submits his prospective stories by e-mail, Facebook, WhatsApp and many phone calls. Even if he does not get an answer, he keeps on submitting stories. She emphasizes that the appropriateness of the stories is always monitored by the informal producer who has a more relevant view than many graduated experienced journalists. Some of his stories have even ended up being made into whole programs, as in the case of the special series "Caipiras" (Hillbillies), $2012^{20}$.

When asked about how faithful the media are to his suggested stories once accepted, Camcorder John says that they generally try to enhance his stories in order to get the public's attention, but he does not see that as a negative thing because he understands that once the stories have been made into news, they become even more interesting.

Camcorder John's working style is similar to what is known as participative or citizen journalism, something that has been increasingly consistent and frequent, especially in social media.

Nevertheless, the quality of such participation comes into question, especially concerning its reliability, scope and relevance. Considering that these aspects must also be questioned in professional journalism, it seems that acquiring specific techniques to obtain and verify news, contextualizing the information and following certain ethical principles are inherent to mediators of journalists, according to Fidalgo. Out of all these specifications, it is the orientation inside the media space which the author presents (he calls it conflicting terrain) within which there are multiple interests (FIDALGO, 2009).

Camcorder John's interest seems to be in trying to make his content media-friendly. He says that he feels proud every time one of his prospective stories is made into news. Apparently, he is driven by media himself because he has adapted his perspective to fit the editorials and their respective public. He weaves his web of narratives from a journalistic viewpoint by looking at the world around him. 


\section{THE NARRATIVES: FROM BENJAMIN TO CONTEMPORARY MEDIA}

According to Camcorder John, his interest in media narratives began in 1977, when his father bought a black and white TV. When they turned it on for the first time, it was playing the 1973 film Negrinho do Pastoreio ${ }^{21}$, directed by Antonio Augusto Fagundes. The protagonist of the film was Grande Otelo. The film tells the popular story of a Southern Brazil folk legend which has been culturally preserved and retold. It has been adapted to different media, from popular storytelling to comics and cinema, including an adaptation of the 1978 Clarice Lispector book (2000) "Como Nasceram as Estrelas Doze Lendas Brasileiras" (How the Stars Were Born - Twelve Brazilian Legends), where the author remakes traditional narratives 22 .

The story of Negrinho do Pastoreio, similar to some European fairy tales, brings impactful elements such as the punishment the boy was submitted to and his death on an anthill. These elements have been softened in some other versions, for example in the adaptation for Turma da Mônica (Monica's gang). In this version, the ants are friendly, they do not devour the boy, and the rancher is not a bad man (SOUSA, 2010)23.

Camcorder John found a new, meaningful contact in media narratives in 1979, adding to his already obsessive passion for filming equipment (he usually takes dozens of photos where he appears standing beside the equipment that reporters take into the city, which he then posts on social media). In the 70's, still a teenager, he was fascinated with the film "Os Três Boiadeiros" (The Three Cowboys), directed by Waldir Kopezky and starring Pedro Bento and Zé da Estrada. It was filmed in Campina do Monte Alegre. John's father was the owner of a restaurant where the production crew used to have meals. His sister, Solange Gomes Aleixo, was an extra in the film.

Benjamin (1982) talked about how hard it was to find someone who knew how to narrate, indicating how difficult it is to find someone who can do it properly. Considering the bleak times in which the text was written (1936) and despite its tragic developments, it is possible to update some of the ideas brought up in it and relate them to Camcorder John's narrative production.

To Benjamin, we seemed to be deprived of a faculty that inherently belonged to us, one of exchanging experiences, something that is the source for all narrators and characterized by two styles: the traveler, who usually brings stories to tell from other lands; and the traditional narrator who has never left his place and, having seen 
and experienced the traditions first-hand, is very familiar with them.

The first hypothesis of this study looked at John Camcorder as a traditional narrator, considering the fact that he had never left Campina do Monte Alegre and usually reported facts about his daily routine. However, as the study developed further and the interviews were analyzed, it was clear that he is actually a narrator; albeit a contemporary one, and also a narrator mediator who knows both the origins of traditions and where to find experienced narrators, people who have lived in Campina for a long time. He also realizes how these narratives should be restructured in order to get the attention of the media. One of his most reliable sources is Mr. Carmo Lourenço Gomes; John's uncle who lives in Campina.

According to Benjamin's concept, Camcorder John is not a traveling narrator. Although he hardly ever leaves Campina, he is a frequent Internet user; he is constantly online, especially on Facebook and WhatsApp creating narratives for: a) mediating others, the traditional narrators, and by creatively elaborating his own stories, a result of his attentive observation of not only the surrounding world, but also the kind of stories the media narrates, inspiring him to appropriate the media language and adapt his discourse to the editorial demands of his contacts; b) being able to use communication technology that gives him the freedom to access the media through any means, something that would be impossible if he still had to submit his stories over the telephone. As mentioned earlier, internet use has really broadened the horizon of Campina by getting news from other places, like the story about a young country singing duo on Bandeirantes TV, on the program "Tá na Tela”24 (It's on the Screen).

Benjamin (1982) explains that the narrative is attributed to a utilitarian dimension, like a moral teaching, a practical suggestion, a proverb or a standard of living. It constitutes a narrator's advice, who extracts the narrative either from his own experience or from other people's experiences. Many of John's stories have a utilitarian element with characters who reflect examples of real life, like the case of Jorgina, a woman who is able to do all her activities on her own, even though she is missing part of her arms and legs ${ }^{25}$.

According to Benjamin, the narrative might even come across like a miracle while the information is still awaiting immediate verification. Camcorder John's stories sometimes tend to be traditional, like the legends about sacis and ghosts. These stories, which are told repeatedly, never grow old due to their wondrous nature, like the story of Negrinho do Pastoreio which John admires for both its traditional and 
media narratives. However, other stories are more informative and can be corroborated from evidence and testimonies, as the case of the photos taken in the Nazi Farm. Some of them serve as evidence; they show the swastika both on the cattle and on some bricks found by Maciel.

By updating Benjamin's concepts about the narrator we can see that, for a contemporary narrator like Camcorder John, the importance of narrating and the narrator, at any point in time, lies in the fact that through narratives one can explain, re-live, transform and criticize one's own life. Nowadays, narrating uses so many different media forms that are available to an increasing number of users including the semiliterate like Camcorder John, who is much more familiar with oral speech. His narratives are somewhat mythical and even a little sensationalist in terms of their creativity, enthusiasm and lack of everyday events, and can be justified as newsworthy when looking at Sodré's thinking (2009), who conceptualizes and questions journalistic objectivity and neutrality:

It is not about deliberate manipulation or lies, but about interpretations that many times use literary fiction as a common resource, aiming to create a more comprehensive, semantic atmosphere. Although it is directed towards neutral storytelling, the news cannot avoid having an emotional appeal found in the stereotypes that come from fiction or parts of a myth. (SODRÉ, 2009, p. 16).

The author explains that "the gist of the ideological objectivity of the news is constituted of the same expressive material used by the former narrator, to cement - with words - the community ties" (SODRÉ, 2009, p. 15).

When transforming Camcorder John's stories into news reports, the media, particularly journalism, exploits the fictional elements of the facts. These fictional elements give the story value, which then attracts the public's attention exactly because of its unbelievable nature. The public's attention to the unusual seems fundamental, both as a component to many of Camcorder John's suggested stories and as a part of traditional media: tales, legends, myths and other related issues.

Camcorder John became known throughout the media as a source to turn to, especially when you wanted something eccentric, funny or poetic; trademark elements of the Record TV news "Balanço Geral". He has branched out with his work; he became a production collaborator for CQC, and submitted stories which were not restrictive to the city of Campina to the program "Proteste Já" (Protest now). He gained popularity on social media and respect in Campina do Monte Alegre, yet he seems to have created the need to constantly produce which, many times, compels him to 
create news that, after being submitted and checked, proves to be missing some facts. They are pseudo facts produced from the logic determined by the information industry and the people's curiosity, thirsty for new stories.

Camcorder John's amazement for media narratives and communication technology (first it was the VHS camera, followed by the internet and the mobile phone) gave him the ability to deal with different cultural codes such as: common and popular communication in rural areas; myths passed down from generation to generation by traditional narrators; and mass communication, from the printed newspaper to television. Even though he did not finish elementary school, Camcorder John dominates the language of internet social media, as well as the very specific and restricted language of media professionals and journalists, including all their distinct forms, structure and jargon that go along with prospective stories, the production of content, and the news, just to name a few. His education has come from his contact with the media and producers and journalists, all the while assimilating the language and discourse of media. Although he was born and grew up in a rural area, he seems to have been able to overcome this situation. Since he acquired his camera, he has had access to other cultures and, at the same time, his stories have managed to put Campina on the regional, national and international media map. He is responsible for supervising and broadcasting part of the news clippings which traditional narrators submit to him as many of them live far away from Campina where transportation service is poor, there is no electricity, and communication is only verbal. Despite his low level of education, Camcorder John works as a translator, translating the oral narratives into either written or audiovisual narratives, and then advertising them on social media and among the public, journalists and producers. Some residents of Campina find it difficult to decode (and even more difficult to code) the media messages and they turn to John for help, who welcomes the journalists and producers to the city, gaining the respect from both the population and the Mayor and other authorities. He is clearly concerned about his apolitical position, defining himself as an assistant to Campina, not to the Mayor. Despite his apparent shyness and reluctance to talk to strangers, he sometimes acts like a press representative and accompanies authorities to the media. In January, 2014, on a visit to the city of Votorantim-SP for an interview at TV Votorantim, the Mayor of Campina do Monte Alegre, Carlos Eduardo Ribeiro, requested he be accompanied by Camcorder John. He is also the one to whom the people turn to when they want to complain about holes in the pavement, to criticize and to report fantastic stories and common facts. He is available both to the population of Campina and the large media agents. It is true 
that he cares about the population and their needs. It is also true that some people in the city (and there are a few of them) believe that John distorts the facts and thus exposes them to ridicule; they neither feel represented by him nor identify themselves with the language used in the news about the city. John's passion for the media is evident; it makes him a translator (but also a distorter) of the local people's codes for the media, which leads him to adjust his discourses and language in order to garner attention.

Camcorder John's role is to sometimes question the dominant authority, but on the other hand, by giving the media the splendor and excitement it desires, he ends up maintaining the separation and marginalization of the rural environment and its characters who are usually featured as odd, superficial, suffer from stereotypes, and lack context. This is the case of journalist Gerson de Souza, who has already reported many of Camcorder John's stories in a more humanistic, simple, and informal way, yet does so carefully and respectfully by approaching the facts and characters in a natural way, as if he were part of that universe, thereby creating an atmosphere of intimacy and simplicity which sometimes elevates the common to poetic ${ }^{26}$. These reports on Camcorder John's stories are escapes from the regular news scheduling of communication media. They do not address the daily lives of the people or their wonderful stories that have told over generations. But they also constitute complaints and demands that are not heard outside of Campina, and force the authorities and even the local and regional media to sit up and take notice as in the case of the complaints about educational books being buried in the backrooms of City Hall ${ }^{27}$. These are journalistic facts and we refer to Pontes and Silva who state:

\footnotetext{
We could still, as Vaz and França (2009) ${ }^{28}$ suggest, think about journalistic facts of different nature. Legitimate journalistic facts investigate the causes and consequences while other, ordinary ones do not collectively produce significant changes, they merely fill up space on the pages and are then made legitimate by the media (2010, p. 55$)$.
}

That is what Camcorder John deals with: the ordinary, the common, things that will not change your daily life, but he also works with the magical and the wonderful. His stories are narratives that precede the news, and they attempt to convince the journalist themselves first, the story tellers, even if they are non-fictional stories.

Even narrating non-fictional elements, he arranges the facts into the format of a story and presents features that identify what type of story he is telling. Many theoreticians deny the narrative in order to give value to the fact, and defend journalism's position within the positive 
sciences. The proliferation of theories centered either on copying events or on the ethical status of journalism is evidence of an abandonment of the narrating potential of texts. (PONTES and SILVA, 2010, p. 59).

Despite the abandonment of the narrating potential, Pontes and Silva highlight that journalists unconsciously continue producing stories with a "symbolic and mythical background which permeate human relations and structure literature" (2010, p. 59). Therefore, perhaps one of Camcorder John's main roles as a narrator is more in appropriating the modern forms of transmitting information, to give the traditional narrators and the invisible groups a voice within the big media; not without its discomforts, crisis, distortions and contradictions that every dialogue presupposes. To journalists, he is a reminder of the narrating character of journalism and the power narratives have to make sense of chaos and understand the world.

\section{FINAL STATEMENTS}

Camcorder John seems to reinvent the everyday life of his city, and himself, by taking Campina do Monte Alegre to the media. He himself states that the media makes the city seem bigger and busier than it really is. John's sister, Solange Gomes Aleixo ${ }^{29}$, an educator, states that her father used to worry about the boy who never wanted to study, saying that one day she would become Dona Solange (Housewife Solange), and her brother, due to his low level of education, would be only Nhô João (Just another John). Thanks to his relationship with the media, today he is Mr. John and not just any mister: Mr. Camcorder John.

Camcorder John's activity can be seen as a form of participative journalism, an opportunity to think about things other than the mundane, and to also understand the different and the wonderful. On the other hand, it seems that instead of highlighting the factual events and their peculiarities in Campina as culture-specific, what the media most look for is a dash of fiction in these facts to solidify them as oddities; in this case that also includes journalism, or at least, a certain kind of journalism.

He is a contemporary narrator who knows his city and its citizens, and is respected by local authorities for bringing Campina do Monte Alegre to the big media, but he is also known as someone who makes complaints, criticizes and knows journalists and communication networks all over Brazil which give the city a symbolic and political power which 
he is totally aware of...not only him, but also the municipal authorities. The former mayor of Campina do Monte Alegre, José Benedito Ferreira ${ }^{30}$ (nicknamed Zé Dito), states that the people should not be upset with John because the accomplishments City Hall has made were usually brought to the media's attention; the journalists were in touch with the informal producer and not the Mayor. Even though CQC went to the city while Mr. Ferreira was in office (April 26, 2010) to follow up on complaints about irregularities in a gas station, which John had registered, it is not reason enough to weaken relationships with him, and could end up making things even worse. Although he does enjoy a good relationship with the media, John also uses it for the common good. However, in one of his stories he sold a dish that was created in Campina but never consumed there - the sweet chouriço ${ }^{31}$. The strange recipe of sweetening a traditionally salty dish does attract attention and raises interest in something that is a little curious, a novelty or eccentricity, which reinforces the oddities, sensationalism and stereotypes the media reports on.

It goes without saying that his fascination with the media led Camcorder John to educate himself in the practice of informal "journalism", even despite his low level of education. He learned from the actual media and the professionals working in it, became literate in the specialized language used in journalism, understood news-values for the appropriate editorials as well as formats or types of language, such as the story, the news, the report and the release. This contact with journalism became even more important after learning to use communication technology which Camcorder John used to solidify and increase his role.

Camcorder John's case is an example of why it is necessary to reflect on journalism as a practice where the audience craves entertainment over information, the texts are increasingly weaker, and the professionals have poor academic backgrounds and lack a definitive role, selecting issues and content within a very tight time frame; content and issues which overlap one another and compete with the ones produced by the average citizen, especially on social media. Thus, it is necessary to reflect on the transformations within journalism not just in terms of the increased audience participation but also the increase in sources.

Camcorder John has extrapolated his role as a source to also play the role of producer. Although he does not have any formal education in journalism, he writes, defines and guides the characters, contacts the editors and accompanies the teams of journalists who come to the city. Although he says he does not do it for a living, he calls it work, 
and is not always paid well for it. On the other hand, for Camcorder John's stories to be printed, he needs other mediators, in other words the professionals who work with him. These are actual professional journalists who sustain the informal journalism he practices.

Camcorder John's work is an example of participative journalism: a citizen without any professional graduation manages to reach the media and, aware of the power they have, acquires a power of his own that is recognized and enjoyed by some yet questioned and contested by other residents of the city. The limits of this kind of relationship need to be determined by the journalists themselves.

As a source, Camcorder John provides the media with a slice of reality (or fiction) that should be developed, looked at from many different angles, and adhere to an ethical status and criteria of relevance and interest - the wide participation of average citizens in journalism cannot change this. Therefore, before prospective stories become narratives they must be filtered through journalism and, only afterwards can they be made into news. If there is a legitimate role for Camcorder John and his intersubjective personality in journalism, it is that of a source.

*This paper was translated by Carlos Fernando Leite and revised by Lee Sharp.

\section{REFERENCES}

AGUILAR FILHO, Sidney. Educação, autoritarismo e eugenia: exploração do trabalho e violência à infância desamparada no Brasil (1930-1945). Campinas: Unicamp, 2011.

BENJAMIN, Walter. O narrador: Considerações sobre a obra de Nikolai Leskov. In: Magia e técnica, arte e política: ensaios sobre literatura e história da cultura. São Paulo: Brasiliense, 1994. p. 197-221.

FIDALGO, António. Especificidade epistemológica do jornalismo: Desfazendo uma ilusão do jornalismo cidadão. In: CARDOSO, Gustavo; CÁDIMA, Francisco Rui; LANDERSET, Luís. Media, Redes e Comunicação. Lisboa: Obercom, 2009. p. 219-230.

MEDITSCH, Eduardo. Jornalismo e construção social do acontecimento. In: BENETTI, Marcia; FONSECA, Virginia Pradelina da Silveira. Jornalismo e acontecimento: Mapeamentos críticos. Florianópolis: Insular, 2010. p. 19-42.

PONTES, Felipe Simão; SILVA, Gislene. Acontecimento jornalístico e história. In: BENETTI, Marcia; FONSECA, Virginia Pradelina da Silveira. 
Jornalismo e acontecimento: Mapeamentos críticos. Florianópolis: Insular, 2010. p. 43-61.

SODRÉ, Muniz. A narração do fato - Notas para uma teoria do acontecimento. Petrópolis: Vozes, 2009.

\section{NOTES}

1 Caboclo: Name given to a person of mixed Indigenous Brazilian and European descent.

2 Interview provided by Gerson de Souza, on Dec. 11/2014.

3 Saci: A Brazilian folklore character whose full name is saci-pererê: a mischievous black boy who usually wears a red hood and red shorts (sometimes he is shown naked) and has a pipe. His pranks consist of hiding objects, scaring travelers and playing with animals.

4 Available at: <https://youtu.be/FBK_p1IT5j4>. Accessed on: Feb. 22, 2015.

5 Available at: <https://youtu.be/WhS3ohlfluc>. Accessed on: Feb. 22, 2015.

6 Available at: <https://youtu.be/Sk54R9iKfoM>. Accessed on: Feb. 22, 2015.

7 Available at: <https://youtu.be/s1Y2LdfaVUU>. Accessed on: Feb. 22, 2015.

8 Available at: <https://youtu.be/Rk35VwSz_wo>. Accessed on: Feb. 22, 2015.

9 Available at: <https://youtu.be/IvnmGa5P8jc>. Accessed on Feb. 22, 2015.

10 Available at: <https://youtu.be/xyw2sFZjDU8>. Accessed on: Feb. $22,2015$.

11 Available at: <https://youtu.be/-3gTcyQLSDs>. Accessed on: Feb. 22, 2015.

12 Available at:<http://www.cruzeirodosul.inf.br/materia/401003meni no-recolhe-restos-de-municao-da-revolucao-constitucionalista- 
de-1932>. Accessed on: Feb. 22, 2015.

13 Two of the many links in which one can verify the effect of the story about the Nazi Farm: <http://youtu.be/KdmfRDRP96c>. Access in Feb. 22th, 2015; <http://pt.wikipedia.org/wiki/Campina_do_Monte_ Alegre>. Accessed on: Feb. 22, 2015.

14 Interview provided on $02 / 12 / 2015$.

15 The release was taken from https://www.facebook.com/filmadora. filmadora?fref=ts, and sent by Camcorder John to several communication networks and generated news at TV Tem and Record.

16 Forró: A specific style of dance originating from the Northeast of Brazil in which a couple dances by making quick twisting movements with the hips, to the rhythm of an accordion, two big drums and a triangle.

17 Interview provided on 01/05/2015.

18 Meditsch's references include: BERGER, Peter L.; LUCKMANN, Thomas [1966]. The social construction of reality: a Treatise in the Sociology of Knowledge. Petrópolis: Vozes, 1985; BERGER, Peter L.; LUCKMANN, Thomas [1995]. Modernidade, pluralismo e crise de sentido: a orientação do homem moderno. Petrópolis: Vozes, 2004; GENRO FILHO, Adelmo. O segredo da pirâmide: para uma teoria marxista do jornalismo. Porto Alegre: Tchê, 1987; LIPPMANN, Walter [1992]. Public Opinion. Richmond: University of Virginia, 1922; PARK, Robert [1904]. The crowd and the public. Chicago: The University of Chicago Press, 1972.

19 Interview provided on 01/05/2015.

20 Available at: <http://rederecord.r7.com/video/conheca-o-estilo-devida-simples-dos-caipiras-5047a51992bb9b7c6b399647/>. Accessed on: Feb. 22, 2015.

21 Negrinho do Pastoreio: The legend of a black former slave boy who was strapped down to an anthill as a punishment. According to the legend, the boy's spirit wanders along the country roads and fields, leading a group of horses. He is also known as a deity to whom people usually ask for help in finding lost objects.

22 Book of Brazilian Children Literarure: LISPECTOR, Clarice. Como nasceram as estrelas: doze lendas brasileiras. Rio de Janeiro: Rocco, 2000. 
23 Book of Brazilian Children Literature: SOUSA, Maurício. Turma da Mônica: lendas brasileiras. Negrinho do Pastoreio. Barueri: Girassol, 2010.

24 Available at: <https://youtu.be/uVgM6mo0_fo>. Accessed on: Feb. 22, 2015.

25 Available at: <https://youtu.be/5xSLV04CKv4>. Accessed on: Feb. $22,2015$.

26 Available at: <https://youtu.be/k3CZaUu6t3M>. Accessed on: Feb. $22,2015$.

27 Available at: <http://www.recordpaulista.com.br/portal/noticias/99 24>. Accessed on: Feb. 22, 2015.

28 Authors' references: VAZ, Paulo B.; FRANÇA, R.O. Entre o legítimo e o legitimado: a explosão dos acontecimentos nas capas de Veja. In: XVIII Compós, 2009, Belo Horizonte. Annals of the XVIII Yearly Encounter of Compós. Belo Horizonte: PUC-MG, 2009.

29 Interview provided in Dec. 2015

30 Interview provided in Dec. 2015

31 Chouriço: Typical salty Brazilian food that originating from Africa which is made from cooked pork blood. In some regions of Brazil it is uncommonly sweet.

Míriam Cristina Carlos Silva is $\mathrm{PhD}$ in Communication and Semiotics. Full professor of the Master's Program in Communication and Culture at Sorocaba University (UNISO). Leader of the Media Narratives Research Group at UNISO, this study was developed with the support of FAPESP. 